\title{
ANALISIS KINERJA KEUANGAN PT KAI SEBELUM DAN SETELAH PENYERTAAN MODAL NEGARA PADA TAHUN 2015
}

Erlang Setyadi ${ }^{1}$ dan Taufik Raharjo ${ }^{2}$

Politeknik Keuangan Negara STAN

E-mail: taufik.raharjo@pknstan.ac.id ${ }^{2}$

\begin{tabular}{l}
\hline INFORMASI ARTIKEL \\
\hline Diterima Pertama: \\
[08 Oktober 2020] \\
Revisi : \\
[10 November 2020] \\
Dinyatakan Diterima \\
[20 November 2020] \\
KATA KUNCl: \\
[Penyertaan Modal Negara, Badan Usaha Milik Negara, Kinerja \\
Keuangan]
\end{tabular}

KLASIFIKASI JEL:

[G320, G340]

\section{ABSTRAK}

Adding State equity participation to State-owned enterprises (SOE) is something the government always does in every fiscal year. The increase in the state capital is carried out with the aim of increasing business capacity or improving the capital structure. Ideally, after receiving additional state capital participation, SOE will have healthier financial performance. In practice, it turns out that there are still SOEs that are still losing money even though they have received additional capital. This study aims to determine the impact of increasing state capital on one of the BUMNs, named PT KAl. This research is a quantitative study using trend analysis of financial ratios. Research shows that after receiving additional capital, the company's debt structure improves, but the efficiency in the use of its assets decreases. This decrease is due to the large number of assets that cannot be used so sales didn't increase as much as the assets.

Key Word: State Equity Participation, SOE, Performance, Financial

Penambahan penyertaan modal Negara kepada Badan usaha Milik Negara (BUMN) adalah hal yang selalu dilakukan pemerintah di setiap tahun anggaran. Penambahan modal negara ini dilakukan dengan tujuan meningkatkan kapasitas usaha atau memperbaiki struktur utang. Idealnya setelah menerima penambahan penyertaan modal negara, BUMN akan memiliki kinerja keuangan yang lebih sehat. Pada praktiknya ternyata masih ada BUMN yang tetap merugi meskipun telah menerima tambahan modal. Penelitian ini bertujuan untuk mengetahui bagaimana dampak penambahan modal negara pada salah satu BUMN yaitu PT KAI. Penelitian ini merupakan penelitian kuantitatif dengan menggunakan analisis tren rasio keuangan. Penelitian menunjukkan bahwa setelah menerima tambahan modal struktur hutang perusahaan membaik, namun efisiensi dalam penggunaan asetnya menurun. Penurunan ini disebabkan banyaknya aset yang masih belum bisa digunakan sehingga belum bisa meningkatkan penjualan.

Kata Kunci: Penyertaan Modal Negara, BUMN, Kinerja, Keuangan 
ANALISIS KINERJA KEUANGAN PT KAI

SEBELUM DAN SETELAH PENYERTAAN MODAL

NEGARA PADA TAHUN 2015

Erlang Setyadi ${ }^{1}$ dan Taufik Raharjo ${ }^{2}$

\section{PENDAHULUAN}

\subsection{Latar Belakang}

BUMN adalah badan usaha yang seluruh atau sebagian besar modalnya dimiliki oleh negara melalui penyertaan secara langsung yang berasal dari kekayaan negara yang dipisahkan. BUMN didirikan oleh pemerintah dengan tujuan di antaranya berkontribusi dalam meningkatkan perekonomian nasional, menyediakan barang dan jasa untuk hajat orang banyak, dan menjadi perintis kegiatan usaha yang belum mampu dilakukan sektor swasta. Kepemilikan Pemerintah di BUMN diwakilkan oleh modal yang disetor kepada perusahaan tersebut dengan proporsi $\geq 50 \%$. Setiap tahun anggaran pemerintah selalu menambah jumlah modal kepada beberapa BUMN. Penambahan modal dilakukan melalui mekanisme Penyertaan Modal Negara. Penyertaan Modal Negara (PMN) merupakan dana APBN yang dialokasikan menjadi kekayaan negara yang dipisahkan atau penetapan cadangan perusahaan atau sumber lain untuk dijadikan sebagai modal BUMN dan/atau perseroan terbatas lainnya dan dikelola secara korporasi. Tujuan penyertaan modal negara dalam Peraturan Pemerintah Nomor 44 Tahun 2005 tentang Tata Cara Penyertaan dan Penatausahaan Modal Negara pada BUMN dan Perseroan Terbatas adalah memperbaiki struktur permodalan BUMN dan perseroan terbatas dan/atau meningkatkan kapasitas usaha BUMN dan perseroan terbatas.

Apabila tanpa melalui pertimbangan yang matang, penambahan PMN kemungkinan tidak memberi hasil sesuai dengan tujuan yang ingin dicapai. Meskipun tujuannya agar BUMN menjadi lebih produktif dan optimal namun dalam praktiknya masih ada BUMN yang setelah mendapatkan penyertaan modal kinerja keuangannya tidak membaik atau tujuan penambahan modal tidak tercapai. Berdasarkan LKPP 2018, masih ada BUMN yang masih merugi meskipun telah menerima PMN seperti PT Krakatau Steel, PT Sang Hyang Seri, dan PT Pertani. Ketiga BUMN tersebut merupakan BUMN yang menerima PMN pada tahun 2015.

Berlandaskan fakta tersebut penulis ingin mengetahui bagaimana dampak PMN pada BUMN lain yang telah menerima penyertaan modal negara pada tahun anggaran yang sama. Di antara 27 BUMN yang menerima PMN pada tahun 2017, penulis tertarik untuk mengetahui kinerja keuangan PT KAI. Tambahan PMN yang diterima PT KAI bernilai sebesar dua triliun rupiah, modal ini diterima dengan tujuan mendukung penugasan yang diberikan oleh pemerintah yaitu membangun jalur trans-Sumatra.
Indonesia Rich Journal, Vol. 1, No. 2, (2020), 108 -122

Penelitian ini bertujuan untuk mengetahui bagaimana hasil dari PMN kepada PT KAl setelah tiga tahun diberikan, apakah telah sesuai dengan tujuannya dan bagaimana dampaknya kepada kinerja keuangan perusahaan jika dibandingkan dengan sebelum menerima penyertaan.

\section{KERANGKA TEORI}

\subsection{Badan Usaha Milik Negara}

Berdasarkan Undang-Undang Republik Indonesia Nomor 19 Tahun 2003 tentang Badan Usaha Milik Negara (BUMN), BUMN adalah perusahaan yang sebagian besar modalnya dimiliki oleh pemerintah melalui penyertaan secara langsung yang berasal dari kekayaan negara yang dipisahkan. Pengertian lain mengenai BUMN berdasarkan Peraturan Menteri Keuangan Republik Indonesia Nomor 246/PMK.06/2016 tentang Penatausahaan Kekayaan Negara Dipisahkan, adalah Perusahaan yang sebagian atau seluruh modalnya dimiliki oleh negara yang diwakili oleh kepemilikan pemerintah dalam perusahaan tersebut.

Badan usaha milik negara didirikan dengan tujuan untuk berkontribusi dalam perekonomian nasional dan meningkatkan penerimaan negara dalam bentuk pajak dan dividen. Bentuknya yang merupakan badan usaha tentu memiliki tujuan untuk mendapatkan keuntungan, namun dalam mencari keuntungan BUMN harus menyediakan barang dan/atau jasa yang bermutu tinggi dan memenuhi kebutuhan hajat hidup orang banyak. Untuk bidang usaha yang susah dimasuki oleh sektor swasta, BUMN bertugas sebagai perintis dalam negara yang menekuni bidang usaha tersebut. Dengan menjadi perintis BUMN bisa membina swasta ataupun koperasi agar bisa mengikuti jejaknya.

\subsection{Penyertaaan Modal Negara}

Pengertian penyertaan modal negara berdasarkan Peraturan Pemerintah Nomor 44 Tahun 2005 tentang Tata Cara Penyertaan dan Penatausahaan Modal Negara adalah pemisahan kekayaan negara dari APBN atau penetapan cadangan perusahaan atau sumber lain untuk dijadikan sebagai modal BUMN dan/atau perseroan terbatas lainnya dan dikelola secara korporasi.

Negara melakukan penyertaan modal negara dengan tujuan tertentu. Berdasarkan Peraturan Pemerintah Nomor 44 Tahun 2005 tentang Tata Cara Penyertaan dan Penatausahaan Modal Negara pada BUMN dan Perseroan Terbatas tujuan penyertaan modal negara adalah memperbaiki struktur permodalan dan/atau meningkatkan kapasitas usaha 
ANALISIS KINERJA KEUANGAN PT KAI SEBELUM DAN SETELAH PENYERTAAN MODAL NEGARA PADA TAHUN 2015

Erlang Setyadi ${ }^{1}$ dan Taufik Raharjo ${ }^{2}$

BUMN. Berdasarkan nota keuangan APBN tahun 2017 menyatakan bahwa Penyertaan Modal Negara secara umum dialokasikan untuk mendukung pencapaian program pemerintah di bidang tertentu, mendukung penugasan yang diberikan pemerintah kepada BUMN, dan mendukung upaya restrukturisasi BUMN.

\subsection{Analisis kinerja keuangan}

Kinerja keuangan adalah suatu kegiatan yang dilakukan perusahaan dalam mengukur prestasi perusahaan dan menggunakan modal secara efektif dan efisien demi tercapainya tujuan perusahaan (Sudarno, 2011). Metode yang digunakan untuk menganalisis kinerja keuangan suatu perusahaan adalah analisis vertikal dan horizontal dan analisis rasio.

Analisis horizontal adalah membandingkan laporan perusahaan setiap tahunnya. dengan analisis ini bisa diketahui kecenderungan/trend perusahaan dari tahun ke tahun apakah meningkat atau menurun. Berbeda dengan analisis horizontal, analisis vertikal membandingkan nilai total dengan nilai tiap akun dalam satu laporan keuangan.

Menurut buku Manajemen Keuangan: Prinsip dan Penerapan yang ditulis oleh Titman, Keown, dan Martin (2018) kinerja keuangan perusahaan dapat dilihat dalam lima ukuran, yaitu: likuiditas, struktur modal, efisiensi, profitabilitas, dan nilai pasar wajar perusahaan. Ukuran-ukuran ini bisa didapatkan dengan metode analisis rasio. Analisis rasio adalah analisis yang menunjukkan hubungan antara komponen yang ada dalam laporan keuangan yang memiliki arti tersendiri tiap rasionya. Rasio ini digunakan untuk membandingkan kinerja perusahaan dari tahun sebelum/setelahnya atau dengan perusahaan lain dalam periode yang sama.

1. Likuiditas

ukuran yang menunjukkan kemampuan perusahaan dalam membayar utang jangka pendeknya menggunakan aset lancar yang dimiliki.

\section{a. Current ratio}

$$
\text { Currentratio }=\frac{\text { Currentasset }}{\text { Currentliabilities }}
$$

Membandingkan seluruh aset lancar dengan seluruh kewajiban jangka pendek yang ada pada laporan posisi keuangan perusahaan. Apabila rasio ini bernilai $>1$, artinya perusahaan mampu membayar seluruh utang jangka pendeknya tepat waktu.
Indonesia Rich Journal, Vol. 1, No. 2, (2020), 108 -122

b. Cash rasio

$$
\text { CashRatio }=\frac{\text { Cashequivalent }}{\text { Currentliabilities }}
$$

Menggambarkan kemampuan perusahaan untuk membayar utang jangka pendeknya hanya menggunakan kas atau aset lain yang setara kas tanpa mengonversikan aset lancar lainnya menjadi kas. Jika rasio yang dihasilkan $>1$ maka perusahaan mampu membayar semua utang jangka pendeknya dengan menggunakan kas. Namun jika terlalu tinggi juga menunjukkan bahwa perusahaan memiliki kas berlebih yang belum dimanfaatkan.

2. Struktur modal

Struktur modal suatu perusahaan bisa dilihat dari rasio leverage. Rasio ini menunjukkan bagaimana perusahaan memperoleh asetnya. Dari rasio leverage bisa diketahui besar aset yang diperoleh dari utang.

\section{a. Debt to assets ratio}

$$
\text { DebtAsset }=\frac{\text { TotalDebt }}{\text { TotalAssets }}
$$

Menggambarkan jumlah proporsi aset yang dibiayai oleh utang. Rasio ini juga menunjukkan berapa nilai aset yang diperlukan untuk melunasi seluruh utang yang dimiliki oleh perusahaan. Semakin rendah rasio yang dihasilkan mencerminkan bahwa sebagian besar aset diperoleh dari ekuitas. Bila nilai rasio $>0,5$ artinya sebagian besar aset dibiayai oleh utang.

b. Debt to equity rasio

$$
\text { DebtEquity }=\frac{\text { TotalDebt }}{\text { Equity }}
$$

Rasio ini menunjukkan berapa pembiayaan utang yang dibutuhkan untuk tiap satu modalnya. Apabila nilanya $>1$ maka sebagian besar sumber pembiayaan berasal dari utang, jika <1 artinya ekuitas adalah sumber pembiayaan yang utama. Jika masih $<1$ maka aman bagi pemilik karena berarti utang dan bunga yang ditanggung perusahaan semakin sedikit sehingga semakin kecil risiko yang ditanggung pemilik atas kegagalan bayar yang mungkin terjadi. 
ANALISIS KINERJA KEUANGAN PT KAI

SEBELUM DAN SETELAH PENYERTAAN MODAL NEGARA PADA TAHUN 2015

Erlang Setyadi ${ }^{1}$ dan Taufik Raharjo ${ }^{2}$

3. Efisiensi

Dalam menganalisis kinerja keuangan, efisiensi perusahaan bisa dilihat dari rasio aktivitas. Dari rasio ini bisa diketahui kemampuan perusahaan dalam melaksanakan aktivitas sehariharinya. Kita bisa melihat kemampuan perusahaan memanfaatkan aktiva/aset yang dimiliki untuk menciptakan penjualan.

a. Total assets turnover rasio

$$
\text { TATO }=\frac{\text { Sales }}{\text { TotalAssets }}
$$

Nilai rasio yang dihasilkan menunjukkan berapa sales yang dihasilkan untuk satu rupiah asetnya. Semakin tinggi nilainya menandakan bahwa perusahaan bisa mengelola asetnya agar menghasilkan sales yang jauh lebih banyak dari aset yang dimiliki. TATO menunjukkan efisiensi perusahaan dalam mengelola asetnya.

b. Fixed asset turnover rasio

$$
F A T O=\frac{\text { Sales }}{\text { Totalfixasset }}
$$

mengukur kemampuan perusahaan untuk menggunakan aset tetapnya secara efisien. Nilai yang dihasilkan dari rasio ini menggambarkan seberapa besar sales yang bisa dihasilkan oleh satu rupiah aset tetap yang dimiliki. Rasio ini cocok untuk perusahaan yang menggunakan aset tetap sebagai faktor utama dalam menghasilkan sales.

4. Profitabilitas

Menunjukkan kemampuan perusahaan untuk menghasilkan laba. Hal yang mempengaruhi tingkat profitabilitas adalah efisiensi perusahaan dalam mengelola aset yang dimiliki dan kemampuan perusahaan untuk mengendalikan biaya yang dikeluarkan untuk menghasilkan keuntungan.

\section{a. Gross profit margin}

$$
G P M=\frac{\text { GrossProfit }}{\text { Sales }}
$$

Rasio ini menunjukkan kemampuan perusahaan untuk mengontrol biaya usaha. Semakin mendekati 1 rasionya maka semakin kecil biaya usaha yang dibutuhkan perusahaan. Ini artinya perusahaan sudah memiliki cost control yang bagus untuk menjalankan bidang usahanya.

b. Operating profit margin

$$
O P M=\frac{\text { NetoperatingIncome }}{\text { Sales }}
$$

Rasio ini menujukan berapa banyak profit yang dihasilkan dari tiap rupiah sales-nya setelah dikurangi beban usaha dan beban operasional. Apabila Nilainya mendekati 1 aritnya cost control yang dimiliki oleh perusahaan sudah bagus. Namun jika rendah perlu dilihat lebih lanjut bagaimana GPM-nya, apabila tinggi berarti ada beban operasional yang cukup besar sehingga perusahaan mendapat operating income yang kecil.

c. Net profit margin

$$
N P M=\frac{\text { NetIncome }}{\text { Sales }}
$$

Nilai rasio mencerminkan kemampuan perusahaan dalam mengelola biaya/beban yang dibuat untuk menghasilkan sales. Rasio ini menunjukkan berapa banyak laba yang didapatkan setelah dikurangi seluruh beban termasuk pajak untuk setiap sales yang dihasilkan. Semakin tinggi rasionya maka mengindikasikan bahwa pengelolaan beban/biaya perusahaan sudah baik, namun jika nilainya kecil perlu ditelusuri kembali faktor apa yang menyebabkan itu bisa terjadi.

d. Operating return on assets

$$
O R O A=\frac{\text { Netoperatingincome }}{\text { TotalAssets }}
$$

menunjukkan kemampuan perusahaan dalam menggunakan aset dan mengontrol biaya. Semakin efisien dalam mengelola aset akan semakin meningkatkan nilai rasio. Apabila cost control-nya baik maka nilai rasio ini juga akan meningkat. Bila nilai yang dihasilkan kecil, perlu diamati apakah penyebabnya karena pengelolaan aset yang tidak efisien atau cost control-nya yang buruk. 
ANALISIS KINERJA KEUANGAN PT KAI SEBELUM DAN SETELAH PENYERTAAN MODAL NEGARA PADA TAHUN 2015

Erlang Setyadi ${ }^{1}$ dan Taufik Raharjo ${ }^{2}$

\section{e. Return on equity}

$$
R O E=\frac{\text { NetIncome }}{\text { Commonequity }}
$$

Menggambarkan kemampuan perusahaan untuk memberikan laba terhadap investasi yang diberikan oleh pemilik perusahaan. Nilai yang dihasilkan dari rasio ini menunjukkan berapa laba yang dihasilkan untuk tiap rupiah yang diinvestasikan. Semakin tinggi nilainya maka semakin banyak pula return yang diberikan kepada pemilik modal. Apabila nilainya rendah artinya return yang diberikan oleh perusahaan yang sedikit untuk pemilik modal.

\section{METODE PENELITIAN}

Analisis dilakukan dengan menggunakan metode analisis horizontal. Metode ini membandingkan rasio keuangan PT KAl dalam rentang waktu tahun 2013 hingga 2018 dengan tujuan mengetahui pergerakan atau trend rasio pada rentang waktu tersebut. Data yang digunakan dalam penelitian ini adalah data sekunder yang bersumber dari laporan keuangan konsolidasian PT KAI tahun 2013 hingga 2018 yang bisa diakses di situs resmi PT KAI. Nilai dalam laporan keuangan yang akan digunakan adalah nilai terbaru, atau nilai yang sudah dilakukan penyajian kembali (restatement).

\section{HASIL PENELITIAN}

\subsection{Hasil analisis kinerja keuangan tiap rasio}

\subsubsection{Likuiditas}

\subsubsection{Current rasio}

Grafik 1. Trend Current Ratio

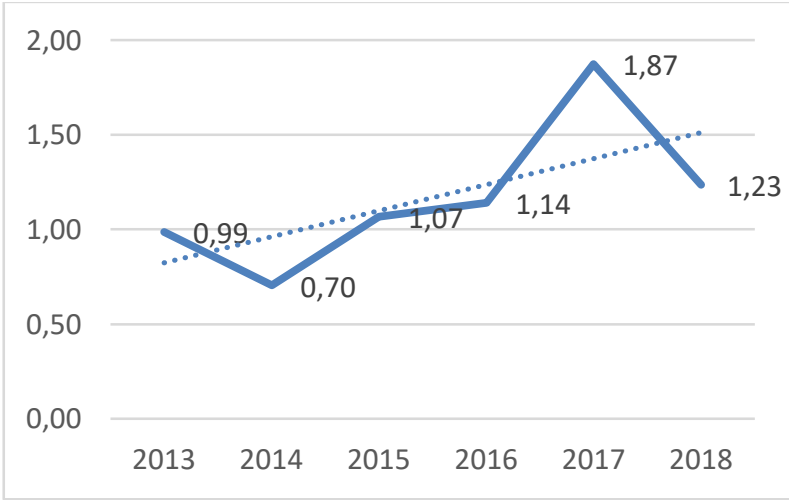

Sumber: Diolah dari laporan keuangan konsolidasian PT KAI tahun $2013-2018$
Tingkat likuiditas PT KAI memiliki trend yang naik dari tahun 2013 hingga 2018. Penurunan current ratio pada tahun 2014 terjadi karena peningkatan akun pinjaman jangka pendek yang dilakukan oleh PT KAI kepada Bank BRI berupa fasilitas kredit modal kerja dengan limit Rp1.800.000.000.000 (satu triliun delapan ratus miliar rupiah) Pada akhir tahun 2014 saldo piutang pada bank BRI sebesar Rp1.792.431.567.478. Hal ini tidak terjadi pada tahun 2013 karena limit kredit modal kerja pada bank BRI masih sebesar Rp900.000.000.000 atau separuh dari limit tahun 2014, karena inilah rasio likuiditas PT KAI turun pada tahun 2014.

Pada tahun 2015 rasio likuiditas meningkat kembali mendekati garis trend. Ini terjadi karena PT KAI mendapatkan penyertaan modal negara. Saldo Aset lancar meningkat karena PT KAI menerima PMN berupa kas yang penggunaannya hanya digunakan untuk penugasan dari pemerintah sehingga penggunaannya tidak bisa untuk membayar piutang jangka pendek yang dimiliki.

Pada tahun 2017 kenaikan rasio lancar disebabkan PT KAI menerbitkan obligasi dan mendapatkan kas sebesar 1,994 triliun rupiah. Selain itu perusahaan juga mendapatkan tambahan penyertaan modal dari pemerintah untuk proyek LRT (dana dibatasi penggunaannya). Obligasi merupakan piutang jangka panjang, oleh karena itu meskipun dari liabilitas tetap meningkatkan current ratio.

\subsubsection{Quick acid ratio}

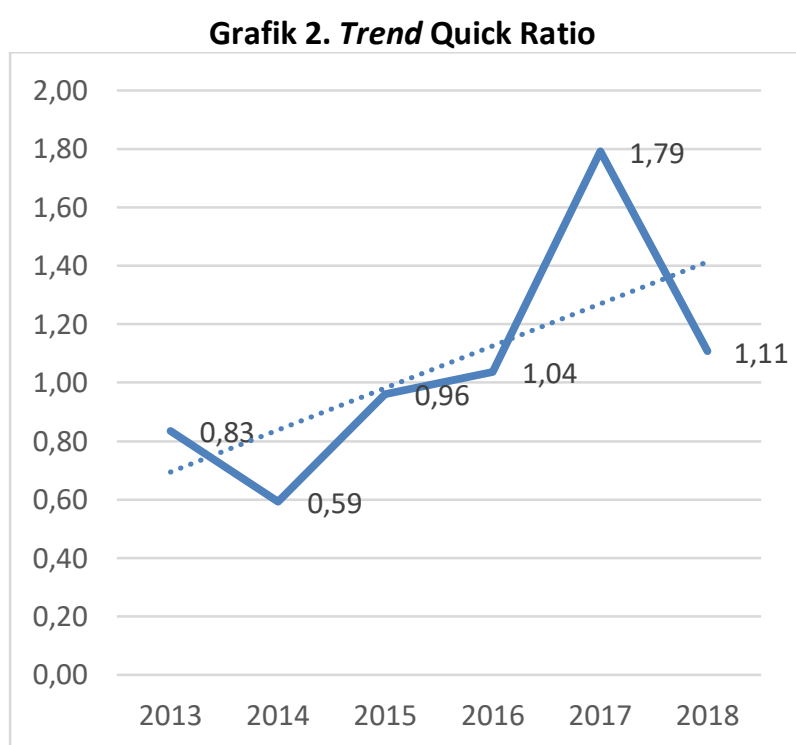

Sumber: Diolah dari laporan keuangan konsolidasian PT KAI tahun $2013-2018$ 
ANALISIS KINERJA KEUANGAN PT KAI SEBELUM DAN SETELAH PENYERTAAN MODAL NEGARA PADA TAHUN 2015

Erlang Setyadi ${ }^{1}$ dan Taufik Raharjo ${ }^{2}$

Jika dibandingkan pola quick ratio tidak jauh berbeda dengan current ratio. Ini menunjukkan bahwa persediaan tidak terlalu mempengaruhi kinerja keuangan dalam PT KAI. Jika dalam perusahaan dagang ataupun manufaktur, persediaan bisa menunjukkan kinerja keuangan suatu perusahaan. Namun dalam kasus PT KAI persediaan yang dicatat bukanlah barang siap jual ataupun barang yang sedang diproduksi. Persediaan dalam laporan PT KAI merupakan suku cadang yang armada lokomotif, gerbong, rel kereta api, dan sarana prasarana lain yang dibutuhkan agar pelayanan tetap berjalan. Sehingga akun persediaan relatif stabil menyesuaikan dengan peningkatan jumlah aset yang dimiliki. Bisa disimpulkan bahwa dengan atau tanpa memperhitungkan persediaan rasio likuiditas tidak jauh berubah dikarenakan nilainya yang stabil dan nilai akun persediaan yang relatif kecil jika dibandingkan dengan akun yang lain. Penggunaan quick ratio tidak terlalu mencerminkan kinerja keuangan PT KAI, mengingat persediaan disini adalah suku cadang dan peralatan pemeliharaan.

\subsubsection{Cash rasio}

\section{Grafik 3. Trend Cash Ratio}

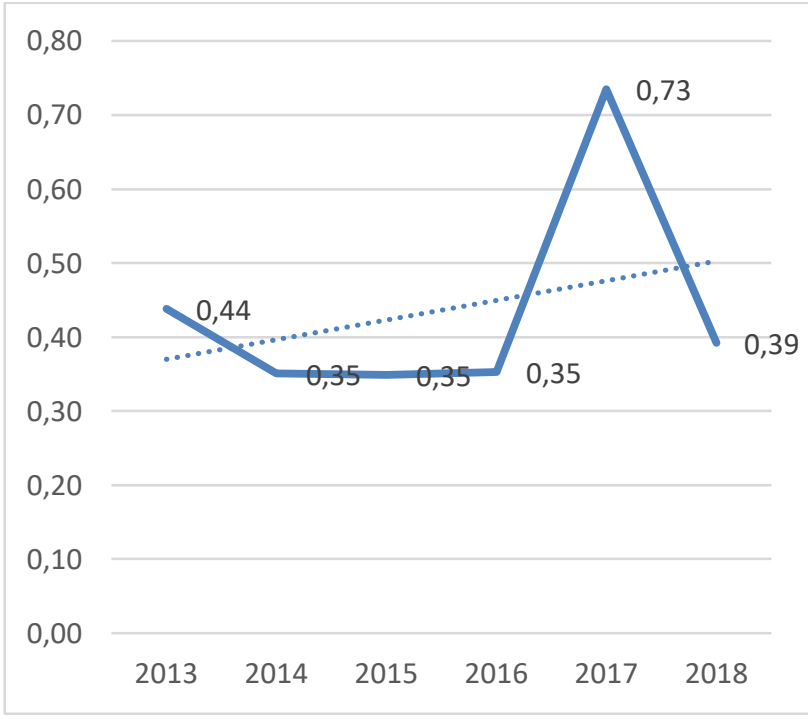

Sumber: Diolah dari laporan keuangan konsolidasian PT KAI tahun $2013-2018$

Jika dilihat cash ratio cenderung stabil dengan rata-rata rasio 0,37 (tidak memperhitungkan nilai rasio tahun 2017). Namun pada tahun 2017 cash ratio meningkat dua kali lipat dari rata-rata. Penyebab peningkatan rasio ini adalah penerbitan surat utang/obligasi yang dilakukan oleh PT KAI. Karena penerbitan surat utang ini PT KAI menerima kas dalam jumlah besar. Tujuan penerbitan obligasi adalah penyelesaian proyek KA Bandara dan pembelian unit. Jika melihat dari rasio tahun 2018 bisa diasumsikan
Indonesia Rich Journal, Vol. 1, No. 2, (2020), 108 -122

bahwa dana dari obligasi sudah terserap sepenuhnya. Artinya PT KAI tidak membiarkan adanya kas idle dalam perusahaannya.

Bila dilihat dari trend-nya, PT KAI cukup baik dalam menjaga cash ratio-nya agar tetap stabil. Artinya dalam mengelola utang jangka pendek PT KAI selalu memperhatikan kemampuannya untuk membayar utangnya berdasarkan kas yang dimilikinya. Selain itu dari rasio ini diketahui bahwa PT KAl mengelola aset lancarnya dengan baik, dalam artian perusahaan tidak membiarkan kas menumpuk.

\subsubsection{Struktur modal}

4.1.2.1 Debt to assets ratio

Grafik 4. Trend Debt to Assets Ratio

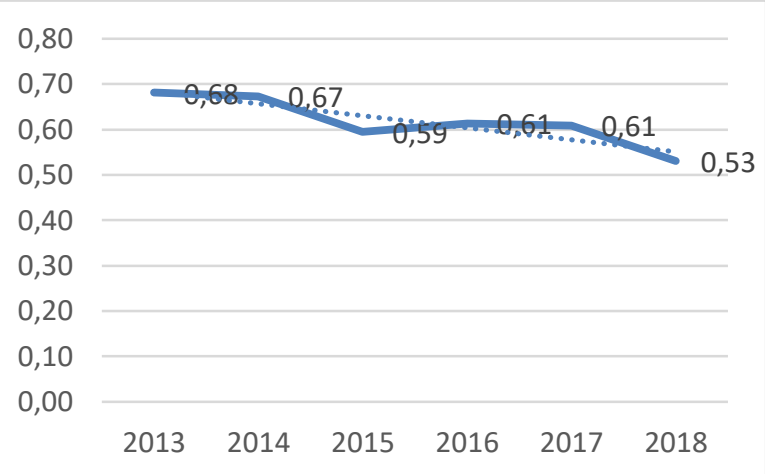

Sumber: Diolah dari laporan keuangan konsolidasian PT KAI tahun $2013-2018$

Berkurangnya nilai rasio pada tahun 2015 karena penyertaan modal negara. Nilai penyertaan modal yang diberikan pada tahun 2015 setara dengan $11 \%$ total aset yang dimiliki pada tahun 2014. Oleh karenanya nilai rasio bisa naik sebesar 0,08 . Pada tahun 2018 penurunan rasio terjadi karena adanya proyek LRT Jabodetabek yang merupakan penugasan dari pemerintah. Proyek ini meningkatkan saldo aset tidak lancar yang dimiliki sebanyak Rp8.754 miliar. Sumber utama pendanaan proyek LRT berasal dari penyertaan modal negara pada tahun 2018. Penyertaan modal negara yang dicatat ditambahkan kepada modal yang disetor bernilai Rp5.600 miliar. Penyertaan yang dilakukan pada tahun 2017 tidak menurunkan rasio karena adanya penerbitan obligasi dengan nilai yang sama besar dengan penyertaan modal yang diterima. 
ANALISIS KINERJA KEUANGAN PT KAI SEBELUM DAN SETELAH PENYERTAAN MODAL NEGARA PADA TAHUN 2015

Erlang Setyadi ${ }^{1}$ dan Taufik Raharjo ${ }^{2}$

Bisa diketahui dari trend ini bahwa penyertaan modal negara memberi pengaruh kepada struktur modal perusahaan. Penurunan yang terjadi banyak dipengaruhi oleh penyertaan modal negara yang dilakukan setiap tahunnya. Hal ini tidak terjadi pada tahun 2016 karena penyertaan modal negara yang dilakukan merupakan penetapan BPYBDS sebagai penyertaan modal negara. BPYBDS sudah diakui dalam ekuitas perusahaan sehingga hanya memindah nilai yang ada pada akun tersebut ke akun penyertaan modal negara yang nantinya menjadi modal saham.

\subsubsection{Debt to equity ratio}

Grafik 5. Trend Debt to Equity Ratio

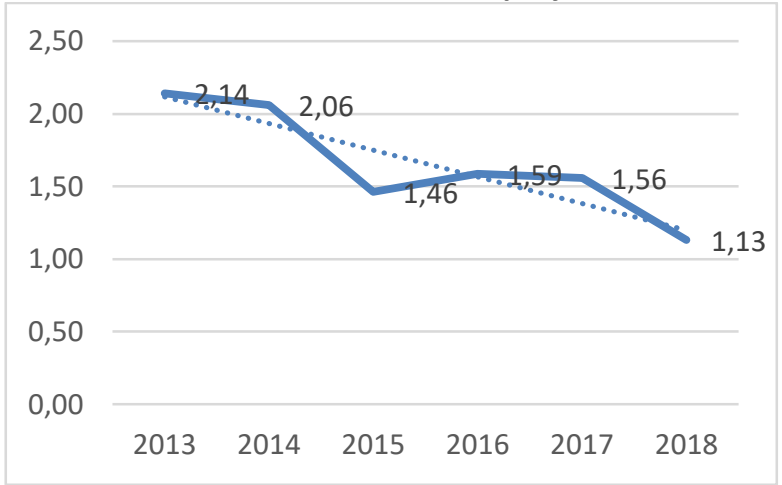

Sumber: Diolah dari laporan keuangan konsolidasian PT KAI tahun $2013-2018$

Selaras dengan rasio debt to total assets, rasio debt to equity juga memiliki trend menurun. Jika tidak ada penyertaan modal negara, rasio ini cenderung stabil. Peningkatan dan penurunannya tak lebih dari 0,14 . Trend menurun ini disebabkan penyertaan modal negara. Hal ini bisa dilihat dari penurunan rasio pada tahun 2015 dan 2018. Pada tahun 2018 rasio mencapai nilai terendahnya selama enam tahun terakhir. Peningkatan rasio pada tahun 2016 karena meningkatnya pinjaman jangka panjang. Salah satu faktor yang menyebabkan naiknya pinjaman jangka panjang adalah pinjaman yang diajukan pada Bank Mandiri. Pinjaman berbentuk pinjaman transaksi khusus dengan limit sebesar Rp1,2 triliun diajukan oleh PT KAI dengan tujuan pengembangan usaha perusahaan di Sumatera Selatan. Selain dipengaruhi oleh penyertaan modal negara, penurunan rasio ini juga dipengaruhi oleh saldo laba yang dimiliki oleh PT KAI. Pada tahun 2013 bernilai Rp0,38 triliun, , saldo ini terus bertambah. Pada tahun 2018 saldo laba yang dimiliki PT KAl sebesar Rp6,06 triliun.
Indonesia Rich Journal, Vol. 1, No. 2, (2020), 108 -122

Pada tahun 2013 dan 2014 trend ini mencapai nilai rasio dua. Artinya setiap satu rupiah modal digunakan, utang yang digunakan untuk membiayai perusahaan adalah dua rupiah. Nilai rasio ini cukup tinggi secara teori, namun PT KAl tetap dipercaya oleh kreditur untuk mendapatkan pinjaman. Faktor yang mungkin mempengaruhi adalah kepemilikan penuh pemerintah atas PT KAl sehingga kemungkinan gagal bayarnya cukup rendah.

\subsubsection{Efisiensi}

\subsubsection{Total assets turnover rasio}

Grafik 6. Trend Total Assets Turnover

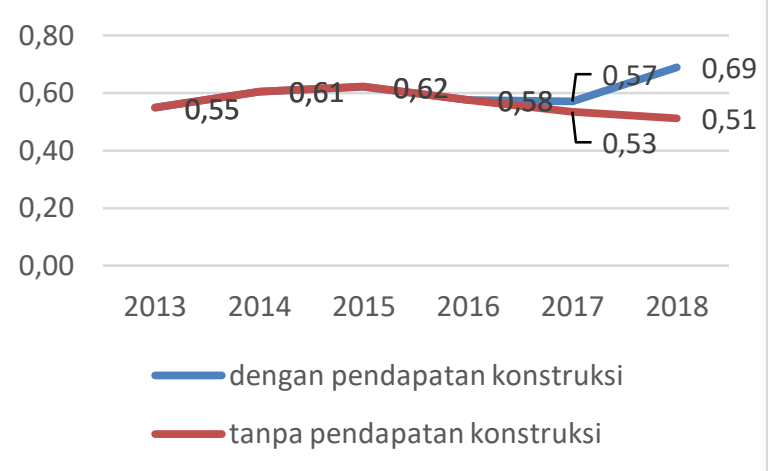

Sumber: Diolah dari laporan keuangan konsolidasian PT KAI tahun $2013-2018$

Nilai rasio ini tidak banyak berubah selama enam tahun, namun pada tahun 2018. Rasio ini meningkat cukup tinggi. Dari pergerakan rasio ini bisa diketahui bahwa penyertaan modal negara pada PT KAI tidak memberi pengaruh yang positif pada efisiensi perusahaan. Hal ini disebabkan bentuk penyertaan negaranya. PT KAI menerima penyertaan modal negara dalam bentuk kas yang peruntukannya hanya untuk membangun LRT Jakarta. Sehingga aset yang dimiliki tidak bisa langsung digunakan untuk menghasilkan pendapatan, ini bisa dilihat dari turunnya rasio ini pada tahun 2016. Artinya peningkatan penjualan tidak sebanding dengan nilai aset yang ditambah.

Namun penurunan tidak terjadi pada tahun 2018, padahal pada tahun ini PT KAl menerima penyertaan modal negara dengan nilai total 5,6 triliun rupiah, dua triliun diterima pada akhir tahun 2017 dan 3,6 triliun diterima pada pertengahan tahun 2018 Peningkatan ini terjadi karena perubahan metode pengakuan pendapatan. Pada tahun 2018 PT KAI menerapkan ISAK 22 tentang Pengungkapan Perjanjian Konsesi Jasa. Ketika PT KAl menyediakan jasa konstruksi atau peningkatan kemampuan, imbalan yang diterima atau akan diterima oleh grup diakui pada nilai wajar. Dengan menerapkan ISAK 22, PT KAI 
ANALISIS KINERJA KEUANGAN PT KAI SEBELUM DAN SETELAH PENYERTAAN MODAL NEGARA PADA TAHUN 2015

Erlang Setyadi ${ }^{1}$ dan Taufik Raharjo ${ }^{2}$

mengakui pendapatan konstruksi dari pembangunan proyek LRT. Pendapatan konstruksi yang didapatkan pada tahun 2018 oleh PT KAI bernilai 6,9 triliun, nilai ini setara dengan $25,7 \%$ pendapatan yang diterima pada tahun tersebut. Jika pendapatan konstruksi diabaikan rasio ini turun, karena aset yang diterima masih belum bisa digunakan atau dalam proses konstruksi.

\subsubsection{Fixed asset turnover rasio}

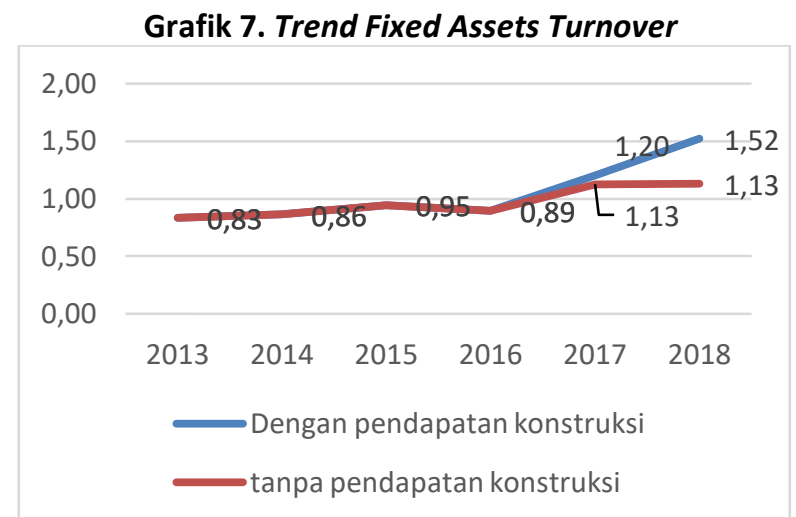

Sumber: Diolah dari laporan keuangan konsolidasian PT KAI tahun $2013-2018$

Tidak jauh berbeda dengan asset turnover peningkatan dan penurunan rasio ini tidak terlalu dipengaruhi oleh penyertaan modal negara. Pertumbuhan rasio yang stabil terjadi pada tahun 2013 hingga 2015. Penurunan yang terjadi pada tahun 2016 menunjukkan bahwa aset tetap yang dimiliki pada saat itu sebagian belum bisa memberikan pendapatan secara optimal. Penyebabnya adalah tahun 2016 masih terdapat sejumlah aset tetap dalam pengerjaan dan nilainya cukup besar.

Peningkatan rasio yang terjadi pada tahun 2017 terjadi karena pendapatan jasa dan barang angkutan meningkat jauh dari tahun sebelumnya, sedangkan aset tetap yang dimiliki hanya sedikit bertumbuh. Selain itu pada penyajian ulang laporan keuangan tahun 2017 juga sudah mengakui pendapatan konstruksi sehingga semakin meningkatkan pendapatan. Pada tahun 2018 kenaikannya sebagian besar dipengaruhi karena pendapatan konstruksi.

Pada dasarnya aset tetap yang dimiliki tidak digunakan untuk menghasilkan pendapatan konstruksi, sehingga jika menyertakan pendapatan konstruksi pada perhitungan fix assets turnover nilai rasio yang dihasilkan kurang mencerminkan kemampuan PT KAI dalam memanfaatkan aset tetapnya. Jika tidak memperhitungkan pendapatan konstruksi nilai
Indonesia Rich Journal, Vol. 1, No. 2, (2020), 108 -122

rasionya menjadi 1,13 . Ini artinya tingkat efisiensi penggunaan aset tetap benar-benar meningkat pada tahun 2017. Namun pada 2018 tidak terjadi perubahan dari tahun sebelumnya.

Alasan mengapa fix assets turnover bisa meningkat pada tahun 2017 dan 2018 sedangkan total assets turnover menurun adalah peningkatan asetnya sebagian besar bukanlah aset tetap melainkan hak pengoperasian aset prasarana. Peningkatan ini berasal dari pembangunan LRT yang dilakukan pada tahun tersebut. Sedangkan aset tetap yang dimiliki PT KAI memiliki pertumbuhan aset tetap yang stabil. Aset LRT yang jelas belum bisa digunakan menurunkan rasio fix assets turnover, namun karena dalam perhitungan fix assets rasio aset LRT tidak diperhatikan maka rasionya lebih tinggi atau meningkat.

\subsubsection{Profitabilitas}

\subsubsection{Gross profit margin}

Grafik 8. Trend Gross Profit Margin

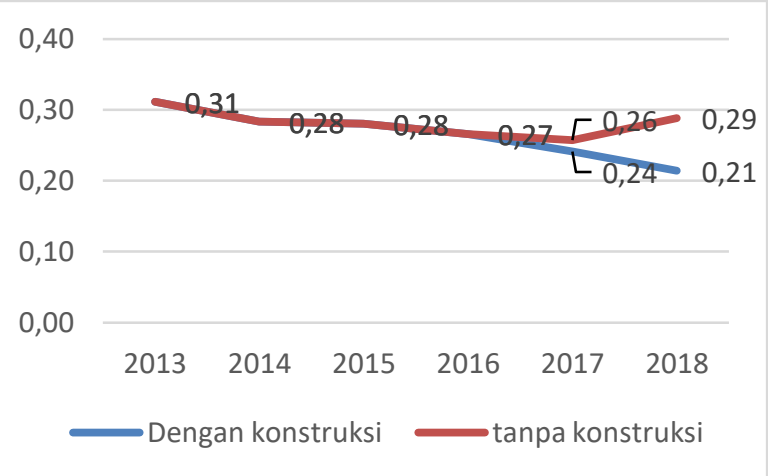

Sumber: Diolah dari laporan keuangan konsolidasian PT KAI tahun $2013-2018$

Rasio ini memiliki trend yang menurun, artinya cost control perusahaan dalam mengelola beban pokok pendapatannya semakin memburuk setiap tahunnya. Meskipun sales/pendapatan yang dihasilkan meningkat setiap tahunnya, laba bruto yang didapatkan bertumbuh lebih lambat daripada pendapatan. Hal ini bisa dilihat dari rasio ini, nilai rasio berkurang terus menerus hingga pada tahun 2018 turun sebanyak 0,1 jika dibandingkan dengan tahun 2013. Penurunan yang terjadi pada tahun 2017 dan 2018 sebagian dipengaruhi oleh pengakuan pendapatan dan beban konstruksi.

Jika pendapatan dan beban konstruksi dari konsesi diabaikan, rasio ini ternyata stabil dengan ratarata nilai rasio sebesar 0,28. Meskipun sempat menurun pada tingkat 0,26, pada tahun 2016 dan 2017 rasio ini kembali meningkat pada tahun 2018. Ini menunjukkan bahwa sesungguhnya profitabilitas PT 
ANALISIS KINERJA KEUANGAN PT KAI SEBELUM DAN SETELAH PENYERTAAN MODAL NEGARA PADA TAHUN 2015

Erlang Setyadi ${ }^{1}$ dan Taufik Raharjo ${ }^{2}$

KAI bila dilihat dari gross profit margin cukup stabil. Penyertaan modal negara yang dilakukan pemerintah belum memberikan pengaruh berarti pada profitabilitas perusahaan bila dilihat dari gross profit margin. Rasio yang stabil menunjukkan bahwa pengaruh yang diberikan penyertaan modal negara kecil.

\subsubsection{Operating profit margin}

Grafik 9. Trend Operating Profit Margin

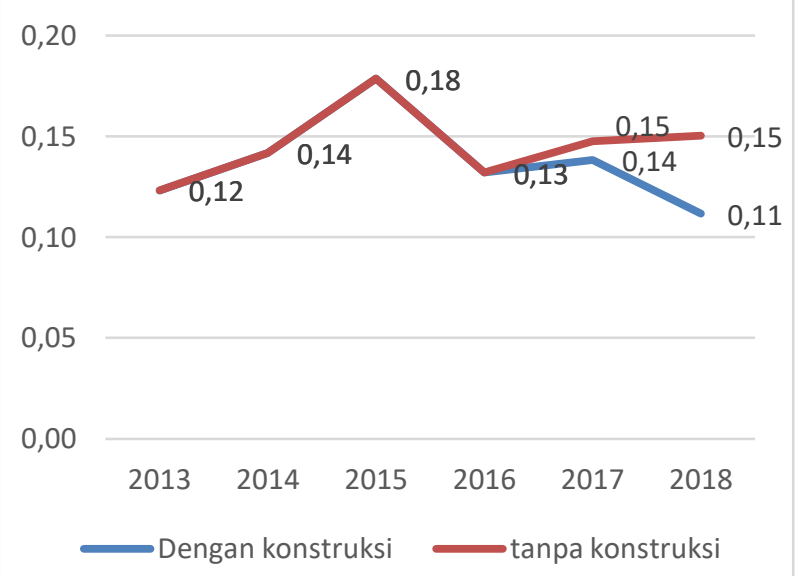

Sumber: Diolah dari laporan keuangan konsolidasian PT KAl tahun $2013-2018$

Pada tahun 2014 peningkatan ini disebabkan penurunan beban usaha dari tahun sebelumnya, sedangkan pendapatan yang diterima meningkat. Padahal pada tahun 2014 gross profit margin perusahaan menurun, ini menunjukkan bahwa perusahaan memiliki cost control yang baik dalam mengelola operating expense. Hal ini juga terjadi pada tahun selanjutnya, namun pada tahun 2016 beban usaha meningkat sebesar Rp493 miliar atau sebesar $35 \%$ dari pengeluaran tahun lalu. Penyumbang terbesar kenaikan ini adalah beban pegawai.

Pengakuan pendapatan konstruksi dan beban konstruksi sangat mempengaruhi nilai rasio pada tahun 2017 dan 2018. Pengakuan pendapatan jasa konstruksi konsesi meningkatkan pendapatan dan beban dengan nilai yang besar, dalam perhitungan rasio meskipun nilai pendapatan dan beban sama bisa mempengaruhi nilai rasio. Jika memperhitungkan pendapatan dan beban konstruksi rasio ini mengalami penurunan pada tahun 2018. Namun jika tidak memperhitungkannya nilai rasionya sama seperti tahun sebelumnya dan nilainya lebih tinggi. Berbeda dengan gross profit margin, operating profit margin dalam tiga tahun pertama semakin tinggi nilainya.

\subsubsection{Net profit margin}

Grafik 10. Trend Net Profit Margin

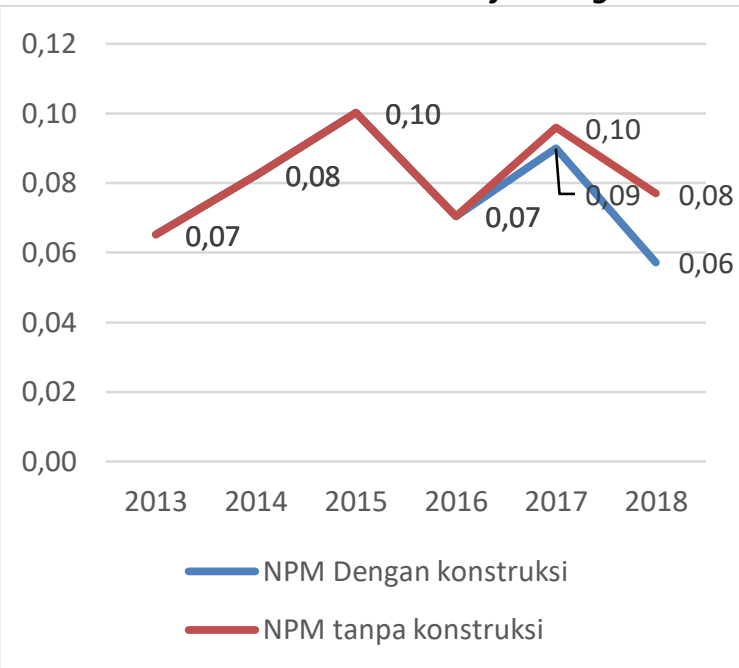

Sumber: Diolah dari laporan keuangan konsolidasian PT KAl tahun $2013-2018$

Sama dengan dua rasio sebelumnya, nilai rasio pada tahun 2017 dan 2018 dipengaruhi oleh pengakuan pendapatan dan beban pekerjaan konstruksi. Pola rasionya sama dengan operating profit margin, yaitu meningkat pada tiga tahun pertama dan menurun pada tahun 2016. Ini menunjukkan bahwa beban pajak dan keuangan pada perusahaan cukup stabil karena peningkatan dan penurunan rasio ini sebagian besar dipengaruhi oleh beban usaha. Dari rasio ini juga diketahui bahwa pada tahun 2016 merupakan tahun dengan profitabilitas terendah secara keseluruhan.

Penyebab utama turunnya profitabilitas perusahaan pada tahun 2016 adalah meningkatnya beban usaha. Beban pokok perusahaan mengalami pertumbuhan sedikit lebih banyak daripada pertumbuhan pendapatan. Kedua hal inilah yang menyebabkan profitabilitas PT KAI rendah. Pada tahun 2016 peningkatan beban pokok lebih besar dari pendapatan yang diterima sehingga pendapatan brutonya lebih rendah jika dibandingkan tahun 2015. Beban usaha naik hampir Rp500 miliar pada tahun 2016, penyebab utamanya adalah kenaikan gaji pegawai sebesar Rp338 miliar. 
ANALISIS KINERJA KEUANGAN PT KAI SEBELUM DAN SETELAH PENYERTAAN MODAL NEGARA PADA TAHUN 2015

Erlang Setyadi ${ }^{1}$ dan Taufik Raharjo ${ }^{2}$

\subsubsection{Operating return on assets}

\section{Grafik 11. Trend Operating Return on Assets}

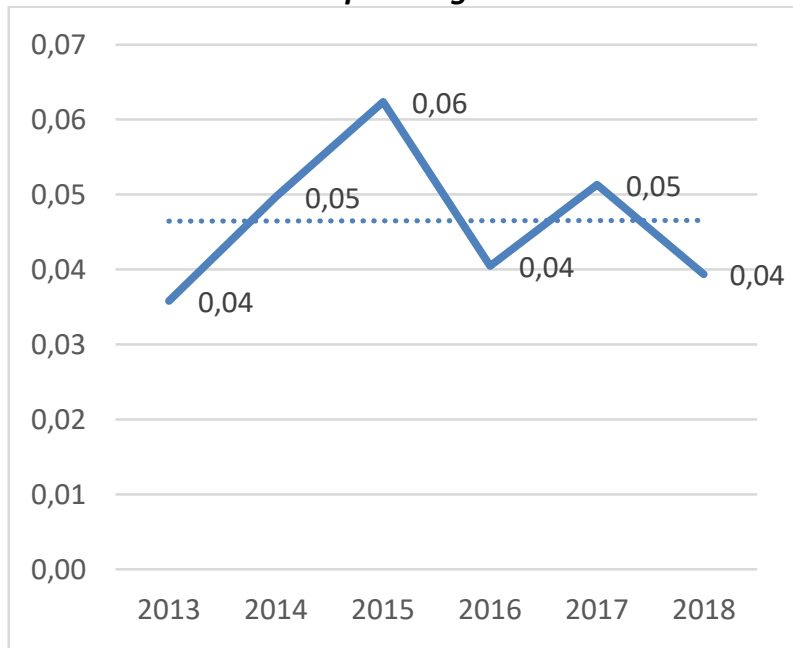

Sumber: Diolah dari laporan keuangan konsolidasian PT KAl tahun $2013-2018$

Jika dilihat dari efisiensi penggunaan aset berdasarkan total asset turnover, efisiensi aset mengalami penurunan pada tahun 2016 sampai dengan tahun 2018. Efisiensi terus menurun karena pada tiga tahun terakhir banyak bertambah aset yang masih dibangun sehingga belum bisa dimanfaatkan. Untuk cost control perusahaan bisa dilihat dari operating profit margin. Rasio Operating profit margin meningkat di tiga tahun pertama, setelahnya menurun pada tahun 2016 lalu meningkat kembali di tahun 2017 dan pada tahun 2018 tidak mengalami perubahan. Rasio operating return on asset menunjukkan kombinasi antara dua rasio tersebut.

Pada tahun 2016 rasio turun dengan nilai 0,04, penyebabnya adalah inefisiensi penggunaan aset dan meningkatnya beban usaha. Meskipun aset sudah bertumbuh sebesar Rp2,74 triliun dari tahun sebelumnya, pendapatan yang diterima tidak jauh dari tahun sebelumnya. Pada tahun 2017 dan 2018 efisiensi aset terus menurun karena masih banyak aset yang belum bisa digunakan, sedangkan cost control-nya kembali membaik. Pada tahun 2018 rasio ini turun karena peningkatan aset dalam jumlah tinggi dan pengakuan biaya konstruksi.

\subsubsection{Return on equity}

\section{Grafik 12. Trend Return on Equity}

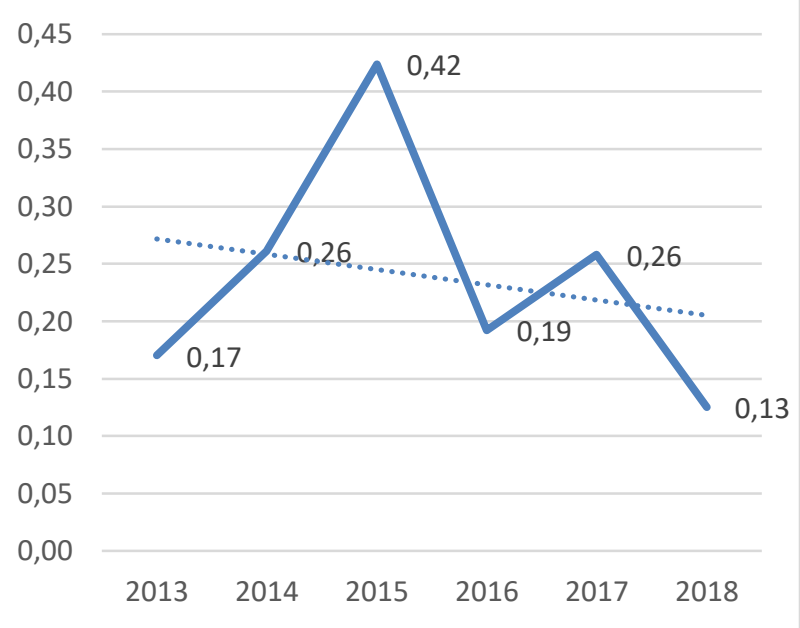

Sumber: Diolah dari laporan keuangan konsolidasian PT KAI tahun $2013-2018$

Rasio ini mengalami perubahan yang tidak stabil dan memiliki trend menurun. Penyebab penurunan rasio ini adalah peningkatan laba tahun berjalan yang tidak sepadan dengan nilai penyertaan modal yang diberikan oleh negara. Penyertaan modal negara yang diberikan akan menambah jumlah modal ditempatkan dan disetor. Jika dibandingkan dengan tahun 2013 jumlah modal disetor pada tahun 2018 meningkat sebesar Rp8,972 triliun atau 272\%. Sedangkan pertumbuhan pendapatan tahun berjalan hanya meningkat sebesar $174 \%$.

Pada tahun 2013 hingga 2015 jumlah modal yang disetor tidak meningkat, yaitu sebesar Rp3,296 triliun. Laba yang diterima pada tahun 2015 tumbuh menjadi 2,5 kali lipat jika dibandingkan dengan tahun 2013. Pada tahun 2016 penyertaan modal negara di tahun sebelumnya sudah dimasukkan dalam saldo modal saham, pendapatannya menurun jika dibandingkan tahun sebelumnya. Pada tahun 2017 penyertaan modal negara dalam bentuk aset/BPYBDS telah dimasukkan dalam modal disetor. Nilai rasio meningkat pada tahun 2017 karena pendapatan yang diterima meningkat $69 \%$ dari tahun 2016 sedangkan modal saham hanya bertumbuh $26 \%$ dari tahun sebelumnya. Pada tahun 2018 modal saham meningkat 84\% dari tahun 2017 penyebabnya adalah penyertaan modal negara sebesar Rp5,6 triliun. Sedangkan laba tahun berjalannya lebih rendah dari tahun 2017. 
ANALISIS KINERJA KEUANGAN PT KAI SEBELUM DAN SETELAH PENYERTAAN MODAL NEGARA PADA TAHUN 2015

Erlang Setyadi ${ }^{1}$ dan Taufik Raharjo ${ }^{2}$

\subsection{Perbandingan Kinerja Keuangan sebelum Menerima PMN dan setelah Menerima}

Penyertaan modal yang diterima oleh PT KAI dalam enam tahun terakhir ada empat. Tiga dalam bentuk kas dan satu dalam bentuk aset. Penyertaan modal dilakukan pada tahun 2015, 2016, 2017, dan 2018. Penyertaan pada tahun 2015,2017, dan 2018 berupa kas, penyertaan ini dilakukan pemerintah agar PT KAI membangun prasarana LRT di Jakarta. Penyertaan yang dilakukan pada tahun 2016 merupakan pengakuan aset BPYBDS sebagai penyertaan modal negara. Secara keseluruhan bisa diketahui bahwa penyertaan modal negara pada PT KAI memberi pengaruh yang cukup besar pada tingkat likuiditas dan struktur modal. Selain itu penyertaan modal negara juga secara tidak langsung mempengaruhi tingkat efisiensi dan profitabilitas.

Dampak penyertaan modal negara bisa dilihat pada tahun 2015, tingkat likuiditas meningkat tinggi, dilihat dari current ratio dan quick ratio-nya. Peningkatan tidak terjadi pada cash ratio karena meskipun penyertaan modalnya dalam bentuk kas, akunnya dipisahkan dari akun kas dan setara kas. Sebelumnya rasio likuiditas current dan quick ratio memiliki nilai di bawah satu setelah penyertaan modal nilainya lebih besar dari satu. Namun tidak bisa diartikan bahwa dana dari penyertaan modal bisa digunakan untuk membayar utang jangka pendek yang ada, mengingat dana yang diberikan sudah memiliki peruntukan.

Struktur perusahaan yang sebelumnya didominasi oleh utang mulai berkurang setelah dilakukan penyertaan modal. Bisa dilihat dari penurunan rasio yang terjadi pada tahun 2015. Penurunan rasio yang terjadi pada tahun-tahun selanjutnya juga merupakan dampak penyertaan modal negara pada tahun masing-masing. Untuk tahun 2016 rasio tidak mengalami penurunan karena akun BPYBDS merupakan bagian dari ekuitas, penyertaan modal negara hanya menghapus akun tersebut dan mengubahnya menjadi akun tambahan penyertaan modal negara. Untuk tahun 2017 penurunan tidak terjadi karena pada saat yang sama PT KAI menerbitkan obligasi dengan nilai yang sama dengan penyertaan modal yang diterima.

Efisiensi perusahaan dalam kasus PT KAI bisa dikatakan menurun, dilihat dari rasio total asset turn over-nya. Pada tahun 2015 meskipun meningkat, nilainya cukup kecil jika dibandingkan dengan tahun sebelumnya. Setelahnya pun nilai rasio ini terus menurun setiap tahunnya. Bila dilihat dari rasio efisiensi yang lain yaitu fix assets turnover, efisiensi perusahaan terus meningkat tiap tahunnya. Ini
Indonesia Rich Journal, Vol. 1, No. 2, (2020), 108 -122

menunjukkan bahwa perusahaan sudah efisien dalam mengelola aset tetapnya, namun tidak untuk aset secara keseluruhan. Hal ini terjadi karena penyertaan modal yang diberikan pada tahun 2015 tidak digunakan hingga akhir tahun 2017. Aset idle inilah yang menyebabkan efisiensi menurun. Dana penyertaan modal negara baru dimanfaatkan pada tahun 2018 untuk membangun aset prasarana LRT, dilihat dari peningkatan akun hak pengoperasian aset prasarana yang meningkat. Meskipun sudah digunakan, proyek pembangunan tersebut belum rampung sehingga tidak meningkatkan efisiensi karena aset yang dimiliki belum bisa menghasilkan pendapatan.

Jika dilihat dari rasio margin seperti gross profit margin, operating profit margin, dan net profit margin penyertaan modal negara tidak memberikan pengaruh apapun. Pertumbuhan ataupun penurunan tidak dipengaruhi oleh penyertaan modal negara yang diberikan. Pendapatan dan beban konstruksi yang dicantumkan pada tahun 2017 dan 2018 merupakan dampak tidak langsung dari penyertaan modal negara. Pembangunan dilakukan dengan menggunakan dana dari penyertaan modal negara sebagai sumber dananya. Pengakuan ini sebenarnya tidak meningkatkan pendapatan, karena tujuannya hanya untuk pengakuan dan pada laba bruto nilainya nol. Jika dilihat dari operating return on assets dan return on equity, profitabilitas perusahaan dinilai menurun. Penurunan operating return on assets dikarenakan aset yang dimiliki masih dalam keadaan idle dan memang belum bisa digunakan. Ini mengakibatkan aset meningkat namun tidak menghasilkan laba usaha yang lebih besar. Begitu juga jika dilihat dari return on equity, jumlah modal yang disetor semakin banyak namun pendapatan yang diterima belum meningkat.

Penyertaan modal pada tahun 2015 tidak memberi dampak kepada kinerja keuangan pada tahun diterimanya selain meningkatkan ekuitas dalam struktur modal. Peningkatan rasio likuiditas diabaikan karena pada dasarnya dana tersebut tidak bisa digunakan untuk membayar utang yang dimiliki. Hal ini sesuai dengan hasil penelitian yang dilakukan oleh Dinarjito (2019) yang menyatakan bahwa penyertaan modal negara yang tidak disertai pertumbuhan aset tetap tidak mempengaruhi kinerja keuangan perusahaan PT KAI pada tahun-tahun setelah PMN kinerja keuangan semakin memburuk jika dilihat dari efisiensi dan profitabilitas, namun struktur modal semakin membaik.

Penyebab penyertaan modal negara tidak memberikan dampak positif terhadap profitabilitas dan efisiensi dalam PT KAI meskipun sudah tiga tahun setelah penyertaan modal pada tahun 2015 adalah pembangunan yang belum selesai. Aset prasarana yang ditugaskan oleh pemerintah untuk dibangun oleh PT 
ANALISIS KINERJA KEUANGAN PT KAI SEBELUM DAN SETELAH PENYERTAAN MODAL NEGARA PADA TAHUN 2015

Erlang Setyadi ${ }^{1}$ dan Taufik Raharjo ${ }^{2}$

KAI belum rampung. LRT Jakarta pada akhir tahun 2018 belum sepenuhnya selesai sehingga belum dapat menciptakan keuntungan bagi perusahaan. Meskipun begitu penyertaan modal negara telah meningkatkan jumlah ekuitas yang dimiliki pemerintah sehingga struktur modalnya membaik..

\section{KESIMPULAN DAN SARAN}

\subsection{Simpulan}

Pada tahun 2015, PT KAI mendapatkan tambahan penyertaan modal negara dari pemerintah. Berdasarkan peraturan pemerintah yang diterbitkan untuk penambahan penyertaan modal, tujuan penyertaan modal pada tahun 2015 adalah memperbaiki struktur permodalan dan meningkatkan kapasitas usaha PT KAI. Selain itu tujuan tersebut disertai penugasan untuk membangun jalur kereta trans Sumatra. Namun penugasan ini dibatalkan dan anggarannya diubah peruntukkannya untuk membangun jalur LRT di Jakarta.

Setelah penyertaan modal pada tahun 2015, pemerintah kembali melakukan penyertaan modal untuk tujuan dan penugasan yang sama, yaitu memperbaiki struktur modal dan membangun aset prasarana LRT. Penambahan penyertaan modal dilakukan pada tahun 2017 dan 2018 dengan nilai total 5,6 triliun rupiah. Selain itu pada tahun 2016 pemerintah juga menerbitkan peraturan pemerintah untuk mengalihkan barang milik negara yang ada pada kementerian perhubungan menjadi milik PT KAI. Pengalihan ini mengakui aset bantuan pemerintah yang belum ditetapkan statusnya sebagai penambahan modal disetor kepada PT KAI.

Setelah melakukan analisis trend diketahui bahwa penyertaan modal negara pada tahun 2015 memiliki pengaruh yang kurang berarti pada kinerja keuangan perusahaan pada tahun diterimanya. Penyertaan ini hanya menaikkan nilai ekuitas sehingga struktur modal membaik. Untuk aspek lain seperti efisiensi dan profitabilitas dampak yang diberikan walaupun kecil cenderung bersifat negatif. Ini terjadi karena penyertaan modal pemerintah yang diterima pada PT KAI pada tahun 2015 hingga akhir periode belum dimanfaatkan. Ini bisa dilihat dari saldo dana dibatasi penggunaannya pada laporan tahunan 2015. Sehingga meskipun ekuitas dan aset meningkat, hal ini tidak meningkatkan pendapatan perusahaan.

Pada tahun 2016,2017, dan 2018 tingkat efisiensi dan profitabilitas semakin menurun. Selain karena penyertaan modal negara pada tahun 2015 yang belum digunakan dan pemerintah menambah kembali penyertaan modal negara kepada PT KAI. Pada
Indonesia Rich Journal, Vol. 1, No. 2, (2020), 108 -122

tahun 2017 dan 2018 total penyertaan modal negara dalam bentuk kas memiliki nilai total sebesar 7,6 triliun rupiah. Penyertaan modal yang diterima pada tahun 2015,2017, dan 2018 digunakan untuk membangun LRT Jakarta pada tahun 2018. Meskipun penyertaan modalnya sudah dimanfaatkan namun pada tahun 2018 rasio profitabilitas dan efisiensi tidak meningkat dan tetap menurun jika dibandingkan tahun sebelumnya. Artinya pendapatan masih belum meningkat meskipun nilai aset tetap dan hak pengoperasian prasarana sudah meningkat karena penggunaan dana PMN. Penyebabnya adalah meskipun nilai aset yang dimiliki bertambah aset tersebut masih dalam tahap konstruksi sehingga tidak bisa meningkatkan pendapatan PT KAI.

Beberapa faktor yang menyebabkan lambatnya pemanfaatan dana yang diterima PT KAI adalah, perubahan kebijakan peruntukan dana yang diberikan, pemberian $\mathrm{PMN}$ yang dicicil, dan proses proyek yang lambat. Penerimaan pada tahun 2015 yang pada awalnya untuk trans-Sumatera diubah peruntukannya untuk membangun LRT setelah PMN-nya diterima. PT KAl yang hanya menerima penugasan tentu menunggu kebijakan pemerintah dalam menggunakan dana tersebut. Penyertaan modal yang diberikan oleh pemerintah pada empat tahun terakhir memiliki tujuan yang sama yaitu percepatan pembangunan LRT. Dana ini tidak diberikan sekaligus sehingga PT KAI menunggu agar dananya terkumpul agar bisa digunakan. Proses pembangunan baru dimulai setelah Peraturan Presiden Nomor 49 tahun 2017 ditetapkan sehingga PT KAI belum bisa menggunakan dana yang dimilikinya, sedangkan sudah menerima dana dari tahun 2015.

Meskipun profitabilitas dan efisiensi perusahaan menurun, tujuan utama penyertaan modal negara sudah tercapai. Tujuan penyertaan modal negara yang dicantumkan dalam setiap peraturan pemerintah untuk memperbaiki struktur permodalan dan meningkatkan kapasitas usaha PT KAI serta mendukung proyek strategis nasional. Proyek strategis nasional yang dimaksud adalah percepatan penyelenggaraan kereta api ringan/light rail transit terintegrasi di Wilayah Jakarta, Bogor, Depok, dan Bekasi. Perbaikan struktur modal terlihat dari penurunan debt ratio, pada tahun 2014 nilai rasio ini sebesar 0,67 nilainya terus menurun hingga pada tahun 2018 rasionya bernilai 0,53. Peningkatan kapasitas usaha PT KAI bisa dilihat dari jumlah total aset yang dimilikinya, pada tahun 2014 total aset yang dimiliki PT KAl sebesar 17,313 triliun rupiah jumlah aset terus bertumbuh hingga tahun 2018 nilai asetnya sebesar 38,996 triliun rupiah. 
ANALISIS KINERJA KEUANGAN PT KAI

SEBELUM DAN SETELAH PENYERTAAN MODAL NEGARA PADA TAHUN 2015

Erlang Setyadi ${ }^{1}$ dan Taufik Raharjo ${ }^{2}$

\subsection{Saran}

Dampak penyertaan modal negara terhadap kinerja keuangan bergantung kepada tujuan penyertaan modal negara dan bagaimana perusahaan mengelola modal tersebut. Apabila peruntukkannya untuk perbaikan struktur modal, ada dua kemungkinan yang bisa terjadi yaitu pemerintah mengubah utang BUMN menjadi penyertaan modal negara atau menambahkan aset kepada BUMN penerima PMN. Selain itu ada juga bentuk penyertaan modal negara yang bertujuan untuk mengalihkan aset milik negara/BMN BPYBDS menjadi aset BUMN. Jika yang dilakukan adalah mengonversi utang yang dimiliki maka kinerja keuangan seperti profitabilitas dan efisiensi tidak akan terpengaruh. Likuiditas perusahaan mungkin meningkat karena sebagian utang yang ada sudah menjadi ekuitas sehingga nilainya berkurang. Dengan mekanisme konversi utang, struktur modal bisa meningkat lebih cepat daripada penambahan aset karena selain menambah ekuitas liabilitas perusahaan juga berkurang.

Apabila melalui mekanisme penambahan aset, perlu diperhatikan lagi apakah aset tersebut bisa digunakan secara bebas atau merupakan penugasan dari pemerintah. Jika penyertaan modal negara dilakukan karena penugasan pemerintah bisa diasumsikan bahwa penugasan yang dilakukan memiliki tingkat profitabilitas yang kecil namun memiliki manfaat sosial yang besar. Karena sifatnya yang kurang menguntungkan namun memiliki manfaat sosial yang besar, pemerintah harus mengatasi hal tersebut melalui BUMN. Penyertaan yang bertujuan untuk mengalihkan BMN BPYBDS menjadi aset milik BUMN biasanya tidak mempengaruhi kinerja keuangan karena pada dasarnya aset tersebut sudah diakui dan digunakan oleh perusahaan. Penyertaan ini hanya memindahkan akun BPYBDS pada ekuitas menjadi modal ditanam dan disetor.

PT KAI dalam kasus ini menerima tambahan penyertaan modal pemerintah dalam bentuk penambahan aset berupa dana dibatasi penggunaannya. Dalam mengelola penyertaan modal yang diterima, PT KAI membiarkan dana yang dimilikinya dalam posisi idle dan tidak segera dimanfaatkan. Meskipun struktur permodalan PT KAI membaik namun terjadi penumpukan aset yang tidak produktif dan menurunkan efisiensi penggunaan aset. Idealnya modal yang diterima harus secepatnya dimanfaatkan agar bisa meningkatkan laba yang didapatkan. Semakin cepat tambahan aset digunakan maka kemungkinan terjadinya penurunan efisiensi dan profitabilitas aset akan semakin kecil. Dalam kasus PT KAI Ini bisa dilakukan jika:
Indonesia Rich Journal, Vol. 1, No. 2, (2020), 108 -122

1. Penyertaan modal dengan tujuan penugasan dari pemerintah diberikan setelah dikaji dan ditetapkan kapan dan bagaimana penggunaannya;

2. Dana diberikan secara sekaligus habis selama satu periode anggaran, sehingga tidak perlu menunggu anggaran terkumpul di perusahaan;

3. Pembangunan yang cepat sehingga aset yang dibangun bisa segera dimanfaatkan.

Apabila hal ini dilakukan terjadinya inefisiensi pada penggunaan aset yang dimiliki bisa diminimalkan. Sehingga dalam jangka waktu dua sampai tiga tahun return on equity kembali atau lebih besar daripada sebelum adanya penyertaan modal negara.

Namun perlu diingat bahwa saran ini hanya terbatas pada kasus yang serupa dengan yang terjadi pada PT KAI. Penyertaan modal negara dalam bentuk konversi utang tidak dapat menerapkan saran ini karena pada dasarnya tidak terjadi pertambahan aset. Perlu diketahui pula bila yang mempengaruhi profitabilitas dan efisiensi bukan hanya penyertaan modal negara. Bila saran sudah diterapkan masih ada faktor lain yang mempengaruhi sehingga rasionya belum tentu akan meningkat.

\section{DAFTAR PUSTAKA (REFERENCES)}

Dinarjito, Agung. 2019. Penyertaan Modal Negara Pertumbuhan Aset dan Kinerja Badan Usaha Milik Negara. https://ojs.unud.ac.id/index.php/Akuntansi/artic le/view/50480/30778 (Terakhir diakses pada 7 Juli 2020)

Ikatan Akuntan Indonesia. 2010. Pernyataan Standar Akuntansi Keuangan (PSAK) No. 34: Kontrak Konstruksi. Jakarta: IAI

Ikatan Akuntan Indonesia. 2010. Pernyataan Standar Akuntansi Keuangan (PSAK) No. 23: Pendapatan. Jakarta: IAI

Ikatan Akuntan Indonesia. 2013. Pernyataan Standar Akuntansi Keuangan (PSAK) No. 24: Imbalan Kerja Jakarta: IAI

Ikatan Akuntan Indonesia. 2015. Pernyataan Standar Akuntansi Keuangan No. 1 Tentang Laporan Keuangan- edisi revisi Jakarta: IAI

Ikatan Akuntan Indonesia. 2016. Interpretasi Standar Akuntansi Keuangan (ISAK) 22: Perjanjian Konsesi Jasa: Pengungkapan. Jakarta: IAI

Ikatan Akuntan Indonesia. 2017. Interpretasi Standar Akuntansi Keuangan (ISAK) 16 : Perjanjian Konsensi Jasa. Jakarta: IAI

Jonatan Sarwono. 2006, Metode Penelitian Kuantitatif \& Kualitatif. Yogyakarta: Graha IImu

Kasmir. 2012. Analisis Laporan Keuangan. Jakarta: PT RajaGrafindo Persada. 
ANALISIS KINERJA KEUANGAN PT KAI

SEBELUM DAN SETELAH PENYERTAAN MODAL NEGARA PADA TAHUN 2015

Erlang Setyadi ${ }^{1}$ dan Taufik Raharjo ${ }^{2}$

Kementerian Badan Usaha Milik Negara. 2019. Laporan Kinerja Instansi Pemerintah 2018.

Keown, Arthur J. Jhon D Martin. William Petty. David F Scott. 2011. Manajemen

Keuangan: Prinsip dan Penerapan, edisi kesepuluh. Jakarta: Indeks.

Pejabat Pengelola Informasi dan Dokumentasi PT KAI. Annual Report PT KAI. https://ppid.kai.id/layanan-berkalaview?_tokenizer=Ng_(Terakhir diakses pada $7 \mathrm{Juli}$ 2020)

Pemerintah Republik Indonesia. 2019 Laporan Keuangan Pemerintah Pusat Tahun 2018 (audited) https://www.kemenkeu.go.id/media/12590/lkp p-2018.pdf (Terakhir diakses pada 7 Juli 2020)

PT Kereta Api Indonesia (Persero) dan Entitas Anak. 2017. Laporan Keuangan Konsolidasian tanggal 31 Desember 2016, 2015, dan 2014 dan untuk tahun yang berakhir pada tanggal-tanggal tersebut beserta laporan auditor independen

PT Kereta Api Indonesia (Persero) dan Entitas Anak. 2018. Laporan Keuangan Konsolidasian beserta Laporan Auditor Independen Per 31 Desember 2017 Dengan Angka Perbandingan Tahun 2016

PT Kereta Api Indonesia (Persero) dan Entitas Anak. 2019. Laporan Keuangan Konsolidasian untuk Tahun-Tahun yang Berakhir pada tanggal 31 Desember 2018 dan 2017 Berserta Laporan Auditor Independen

PT Kereta Api Indonesia (Persero). 2014. Laporan Keuangan Konsolidasian dan Informasi Tambahan untuk Tahun-Tahun yang Berakhir 31 Desember 2013 dan 2012 dan Laporan Auditor Independen.

PT Kereta Api Indonesia (Persero). 2015. Laporan Keuangan Konsolidasian beserta Laporan Auditor Independen tanggal 31 Desember 2014 dan tahun yang berakhir pada tanggal tersebut.

PT Kereta Api Indonesia (Persero). 2016. Laporan Keuangan Konsolidasian beserta Laporan Auditor Independen tanggal 31 Desember 2015 dan tahun yang berakhir pada tanggal tersebut.

PT Kereta Api Indonesia. Sekilas KAI. https://kai.id/corporate/about kai/ (Terakhir diakses pada 7 Juli 2020)

Sudarno, Idrus, M. S., Salim, U., \& Djumahir. 2011. Pengaruh Penyertaan Modal terhadap Pertumbuhan Aktiva, Efisiensi dan Kinerja Keuangan pada Badan Usaha Milik Daerah (BUMD) (Studi pada BUMD/Perusahaan Daerah di Propinsi Riau). https://jurnaljam.ub.ac.id/index.php/jam/article Lview/245/276 (Terakhir diakses pada 7 Juli 2020)
Indonesia Rich Journal, Vol. 1, No. 2, (2020), 108 -122

Pemerintah Republik Indonesia. 2003. Undang-Undang Republik Indonesia Nomor 17 Tahun 2003 tentang Keuangan Negara. Jakarta: Sekretariat Negara.

Pemerintah Republik Indonesia. 2003. Undang-Undang Republik Indonesia Nomor 19 Tahun 2003 tentang Badan Usaha Milik Negara. Jakarta: Sekretariat Negara.

Pemerintah Republik Indonesia. 2007. Undang-Undang Republik Indonesia Nomor 23 Tahun 2007 tentang Perkeretaapian. Jakarta: Sekretariat Negara

Pemerintah Republik Indonesia. 2007. Undang-undang No. 40 tahun 2007 tentang Perseroan Terbatas. Jakarta: Sekretariat Negara.

Pemerintah Republik Indonesia. 2005. Peraturan Pemerintah Republik Indonesia Nomor 44 Tahun 2005 Tentang Tata Cara Penyertaan dan Penatausahaan Modal Negara pda Badan Usaha Milik Negara dan Perseroan Terbatas. Jakarta: Sekretariat Negara

Pemerintah Republik Indonesia. 2015. Peraturan Pemerintah Republik Indonesia Nomor 131 Tahun 2015 Tentang Penambahan Penyertaan Modal Negara Republik Indonesia ke Dalam Modal Saham Perusahaan Perseroan (Persero) PT Kereta Api Indonesia. Jakarta: Sekretariat Negara

Pemerintah Republik Indonesia. 2016. Peraturan Pemerintah Republik Indonesia Nomor 72 Tahun 2016 Tentang Perubahan atas Peraturan Pemerintah Nomor 44 Tahun 2005 Tentang Tata Cara Penyertaan dan Penatausahaan Modal Negara pada Badan Usaha Milik Negara dan Perseroan Terbatas. Jakarta: Sekretariat Negara.

Pemerintah Republik Indonesia. 2016. Peraturan Pemerintah Republik Indonesia No. 52 tahun 2018 tentang Penambahan Penyertaan Modal Negara Republik Indonesia ke Dalam Modal Saham Perusahaan Perseroan (Persero) PT Kereta Api Indonesia. Jakarta: Sekretariat Negara

Pemerintah Republik Indonesia. 2017. Peraturan Pemerintah Republik Indonesia No. 59 Tahun 2017 Tentang Penambahan Penyertaan Modal Negara Republik Indonesia Ke Dalam Modal Saham Perusahaan Perseroan (Persero) PT Kereta Api Indonesia. Jakarta: Sekretariat Negara

Pemerintah Republik Indonesia. 2018. Peraturan Pemerintah Republik Indonesia No. 26 tahun 2018 tentang Penambahan Penyertaan Modal Negara Republik Indonesia ke Dalam Modal Saham Perusahaan Perseroan (Persero) PT Kereta Api Indonesia. Jakarta: Sekretariat Negara

Pemerintah Republik Indonesia. 2015. Peraturan Presiden Nomor 98 Tahun 2015 Tentang Percepatan Penyelenggaraan Kereta Api 
ANALISIS KINERJA KEUANGAN PT KAI

Indonesia Rich Journal, Vol. 1, No. 2, (2020), 108 -122
SEBELUM DAN SETELAH PENYERTAAN MODAL

NEGARA PADA TAHUN 2015

Erlang Setyadi ${ }^{1}$ dan Taufik Raharjo ${ }^{2}$

Ringan/Light Rail Transit Terintegrasi di Wilayah Jakarta, Bogor, Depok, dan Bekasi. Jakarta: Sekretariat Negara.

Pemerintah Republik Indonesia 2017. Peraturan Presiden Nomor 49 Tentang Perubahan Kedua atas Peraturan Presiden Nomor 98 Tahun 2015 tentang Percepatan Penyelenggaraan Kereta Api Ringan/Light Rail Transit Terintegrasi di Wilayah Jakarta, Bogor, Depok, dan Bekasi. Jakarta: Sekretariat Negara.

Pemerintah Republik Indonesia. 2016. Peraturan Menteri Keuangan Republik Indonesia Nomor 246/PMK.06/2016 tentang Penatausahaan Kekayaan Negara Dipisahkan. Jakarta: Sekretariat Negara. 